\title{
PENERAPAN LEADER MEMBER EXCHANGE \\ DALAM PENDIDIKAN KEJURUAN
}

\section{Suryo Hartanto}

Dosen Tetap Program Studi Pendidikan Matematika Universitas Riau Kepulauan Batam

Peningkatan mutu sumber daya manusia dalam pembangunan, merupakan sarana wajib yang harus dikembangkan. Pendidikan merupakan salah satu sarana utama dalam mengembangkan sumberdaya, dengan adanya sumber daya manusia yang berkualitas maka tujuan pembangunan menciptakan masyarakat adil dan makmur akan tercapai. Salah satu peran pendidikan adalah dengan dikembangkanya pendidikan kejuruan. Pendidikan kejuruan merupakan jawaban yang dianggap tepat dalam upaya menciptakan sumberdaya manusia yang baik sesuai dengan kebutuhan dunia kerja di masyarakat. Salah satu jenis pendidikan kejuruan yang dikembangkan saat ini adalah Sekolah Menengah Kejuruan, pada Peraturan Pemerintah No.29 Tahun 2005 menjelaskan bahwa Pendidikan Menengah Kejuruan mengutamakan penyiapan siswa untuk memasuki lapangan kerja serta mengembangkan sikap profesional. Sekolah Menengah Kejuruan (SMK) sebagai bentuk satuan pendidikan kejuruan sebagaimana ditegaskan dalam penjelasan Pasal 15. Undang-Undang Sistem Pendidikan Nasional (Sisdiknas), merupakan pendidikan menengah yang mempersiapkan peserta didik terutama untuk bekerja dalam bidang tertentu. Menurut Calhoun dan Finch.(1982:2), sekolah kejuruan adalah organized educational program which are directly related to the preparation of individuals paid or unpaid employment or for additional preparation for a career requiring other than baccalaureate or advantage degree,(Diselenggarakannya program pendidikan ini secara langsung terkait dengan persiapan individu dalam pekerjaan atau untuk persiapan pengembangan karir yang dibutuhkan selain gelar kesarjanaan).

Dalam menjalankan sebuah lembaga dalam hal ini pendidikan kejuruan, sangat dibutuhkan seorang pengerak atau motor yang mampu menjalankan dan mengembangkan lembaga dan institusi menuju kepada arah yang labih baik. Pemimpin harus memiliki keahlian khusus sebagai komunikator, motivator, pengambil keputusan. Menurut Bass (1985) proposed that 
transformational leadership was characterized by four factors. These factors included; charisma that involved the followers respect and trust for the visionary leader; inspirational motivation which involved using symbols or emotional appeals to gain support for the vision; intellectual stimulation which dealt with encouraging followers to think about old problems in new ways; and individual consideration which reflected the personal concern expressed by the leader for the follower, (kepemimpinan transformasional ditandai oleh empat faktor. Antara lain : karisma pemimpin visioner adalah melibatkan bawahan untuk hormat dan memeberikan kepercayaan, motivasi inspirasional yaitu menggunakan simbol atau daya tarik emosional untuk mendapatkan dukungan dalam mewujudkan visi; stimulasi intelektual ditandai dengan mendorong bawahan untuk berpikir tentang masalah-masalah lama dengan cara baru, dan pertimbangan individu yang mencerminkan keprihatinan pribadi hal ini diungkapkan pemimpin kepada bawahan secara langsung).

Kondisi kepemimpinan dalam lingkungan pendidikan kejuruan di Indonesia, secara nyata kebanyakan tidak menunjukkan bahwa pemilihan pemimpin dalam pendidikan kejuruan masih jauh dari kebutuhan kepemimpinan yang sesungguhnya. Pemimpin dalam hal ini misalnya adalah kepala sekolah, masih sering melibatkan unsur politik dan kepentingan golongan, sehingga terjadilah kepemimpinan yang tidak layak, artinya bukan terpilih pemimpin yang kompeten terhadap kebutuhan pengembangan pendidikan kejuruan. Unsur kepentingan politik dan golongan sering menimbulkan mutasi antar jabatan yang dapat menghambat perkembangan pendidikan kejuruan. Muhransyah (2013) menyampaikan "Selama ini, yang menjabat kepala sekolah hanya merupakan usulan dari Dinas Pendidikan (melalui usulan / rekomendasi kepala sekolah dan atau pengawas). Sedangkan tidak ada yang tahu mereka profesional mengajar atau tidak, pintar jadi kepala sekolah atau cuma pintar melobi atasan. Untuk jadi kepala sekolah juga tidak boleh sewenang-wenang, harus mengikuti proses yang telah ditetapkan, sebab selama ini ada beberapa daerah dan instansi yang mengangkat kepala sekolah tanpa mengikuti prosedur yang telah ditetapkan. Bahkan ada juga kepala sekolah setelah 2 kali menjabat tidak dilakukan rotasi. Jangan ada lagi promosi ataupun rotasi kepala sekolah berdasarkan kekerabatan dan timbal balik politik, misalnya karena pernah menjadi tim sukses. Peran sentral kepala sekolah sebagai lokomotif perubahan jangan di jadikan alat tawar politik waktu pilkada, sehingga orangorang yang menduduki posisi kepala sekolah hanya berdasarkan politik balas jasa". Masih mencontohkan sekolah kejuruan, sudah sangat jelas dalam Permendiknas No. 28 Tahun 2010 
tentang penugasan guru sebagai kepala sekolah/madrasah pada Pasal 1 ayat 5, ketentuan umum menyebutkan, kompetensi kepala sekolah/madrasah adalah pengetahuan, sikap dan keterampilan pada dimensi-dimensi kompetensi kepribadian, manajerial, kewirausahaan, supervisi, dan sosial. Dipertegas dengan pasal 5 tentang pelaksanaan test administratif dan akademik. Sejalan dengan Peraturan Pemerintah, pemimpin dalam pendidikan kejuruan seharusnya memiliki visi dan misi perubahan, dalam Bass (2000), Local line leaders in the organization and high level executives as well as internal networkers and community leaders are needed who can motivate and direct the organization and its members. to learn to adapt to the changes, (Pemimpin, dalam sebuah organisasi dan eksekutif tingkat atas maupun dalam hubungan internal serta tokoh masyarakat diperlukan orang yang mampu memotivasi, mengarahkan organisasi dan anggotanya,belajar beradaptasi dengan perubahan).

\section{Pembahasan}

\section{Leader Member Exchange Theory.}

Pengembangan teory LMX, pertama kali dijelaskan oleh Dansereau, Graen, \& Haga, Graen \& Cashman, and Graen pada sekitar tahun 1976. Teori kepemimipinan, pertukaran pemimpinanggota terfokus pada hubungan dua arah (hubungan diad/Dyadic Relationship) antara atasan dan bawahan. Teori ini mengasumsikan bahwa para pemimpin mengembangkan pertukaran dengan masing-masing bawahannya, dan bahwa kualitas pertukaran ini mempengaruhi hubungan tangung jawab bawahan ,mempengaruhi keputusan, akses ke sumber daya dan kinerja, hal seperti ini disebut dengan Vertikal Dyad Linkage. Teori pertukaran pemimpinanggota berfokus pada peningkatan keberhasilan organisasi dengan menciptakan hubungan yang positif antara pemimpin dan bawahan. Menurut Graen dan Uhl-Bien (1995) dalam LMX terdapat tiga hal penting yang harus dijalankan yaitu respect, trust dan obligation. Hubungan antar atasan dan bawahan dapat terbentuk dengan adanya saling menghormati (respect) terhadap kemampuan orang lain,dengan adanya rasa percaya (trust) yang timbal balik atasan dan bawahan, hal ini selanjutnya diperkirakan bahwa pengaruh kewajiban (obligation) akan berkembang menjadi suatu hubungan kerja.

Penelitian psikologis dalam teori LMX telah terbukti secara empiris kegunaannya dalam memahami proses kelompok. The natural tendency for groups to develop into subgroups and 
create a clique of an in-group versus and out-group has been found by researchers ( Bass, 1990).

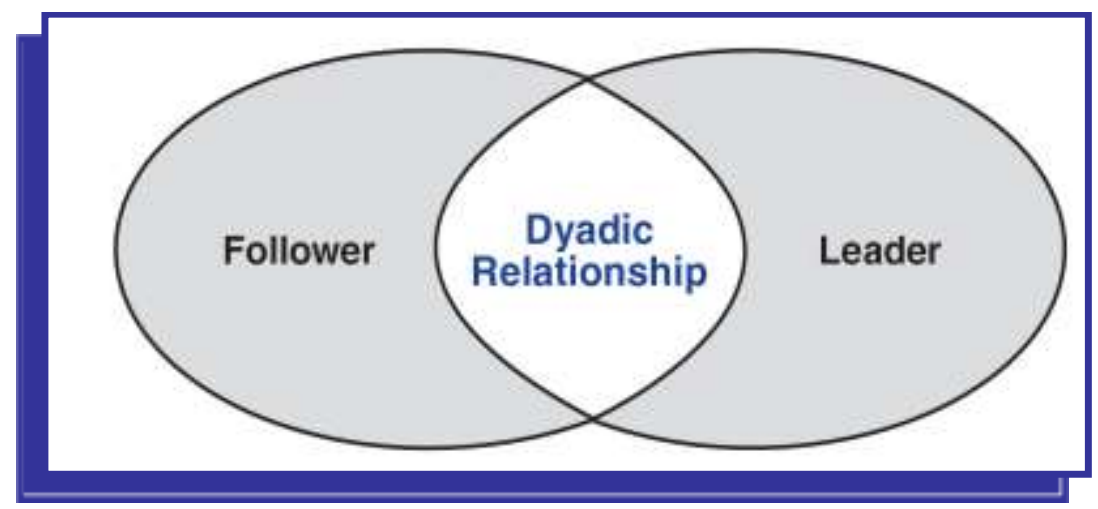

Gambar.1 Dimensi Kepemimpinan LMX

\section{Konsep In-group dan out-group dalam $L M X$}

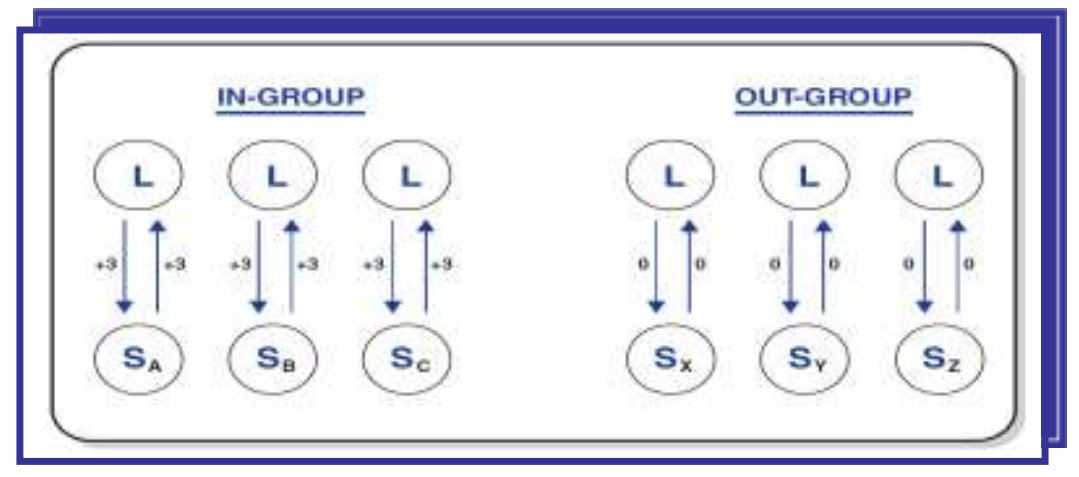

Gambar.2 In-group dan Out-group LMX

Dalam perkembanganya teori kepemimpinan LMX, terdapat konsep In-group dan out-group, seperti yang digambarkan pada gambar.2. Pada gambar tersebut dapat dijelaskan bahwa sebuah organisasi dilihat dari hubungan dan interaksi antara atasan dan bawahan, yang dikelompokkan menjadi dua, yaitu in-group dan out-group, dalam in-group, hubungan ditandai dengan adanya saling percaya, menghormati, saling membutuhkan, dan saling mempengaruhi, pertukaran informasi yang baik, meningkatnya kepercayaan diri, dan saling memberikan perhatian, sedangkan dalam out-group, hubungan yang timbul antara atasan-bawahan ditandai dengan adanya komunikasi formal yang mempunyai kecenderungan berdasarkan hanya kepada deskripsi pekerjaan saja. Perbedaan antara dua kelompok ini adalah tingkat kedekatan hubungan dan interaksi antara pimpinan dan bawahan. Karyawan yang memiliki hubungan dan interaksi yang 
tinggi antara pimpinan dan bawahan masuk dalam kelompok in-group dan di luar kelompok ingroup adalah kelompok out-group."

Pada in-group, bawahan lebih dipercaya, mendapatkan perhatian dalam porsi yang lebih besar dari atasan, dan mendapatkan hak-hak khusus (Robbins, 2007:368). Bawahan yang tergabung dalam out-group mendapatkan waktu yang terbatas dari atasannya dan hubungan antara atasan dan bawahan berdasarkan pada hubungan formal yang biasanya dapat dilihat dari penggunaan bahasa pada saat berkomunikasi (Robbins, 2007:368). Konsep kepemimpinan LMX pada perkembangan selanjutnya tidak lagi melihat konsep in-group dan out-group namun lebih terfokus pada kualitas pertukaran antara pimpinan dan bawahan, untuk lebih menghasilkan hal yang lebih positif. Kualitas pertukaran antara pimpinan dan bawahan yang baik maka akan menghasilkan : kurangnya perputaran karyawan, evaluasi kinerja yang lebih positif, tingginya frekuensi promosi, komitmen kepada organisasi yang lebih besar, penugasan kerja lebih disenangi, sikap kerja lebih baik, lebih banyak perhatian dan dukungan dari pemimpin, partisipasi yang lebih besar, kemajuan karir lebih cepat. Terdapat fase-fase dalam kepemimpinan LMX yang digambarkan pada tabel berikut:

Fase Interaksi LMX

\begin{tabular}{|l|l|l|l|}
\hline Fase & $\begin{array}{l}\text { Tahap 1 } \\
\text { Asing }\end{array}$ & $\begin{array}{l}\text { Tahap 2 } \\
\text { Perkenalan }\end{array}$ & $\begin{array}{l}\text { Tahap 3 } \\
\text { Persekutuan }\end{array}$ \\
\hline Peran & Tertulis & Pengujian & Negosiasi \\
\hline Pengaruh & Satu Arah & Campuran & Timbal Balik \\
\hline Pertukaran & $\begin{array}{l}\text { Kualitas } \\
\text { Rendah }\end{array}$ & $\begin{array}{l}\text { Kualitas } \\
\text { Moderat }\end{array}$ & $\begin{array}{l}\text { Kualitas } \\
\text { Tinggi }\end{array}$ \\
\hline Kepentingan & Diri Sendiri & $\begin{array}{l}\text { Diri Sendiri dan } \\
\text { Orang Lain }\end{array}$ & Kelompok \\
\hline & \multicolumn{3}{|c|}{ Waktu } \\
\hline
\end{tabular}

\section{Pola Kepemimpinan Pendidikan Kejuruan}

Pendidikan vokasi atau pendidikan kejuruan secara garis besar mengalami perkembangan yang cukup pesat, seiring dengan pertumbuhan dan kebutuhan dunia kerja. Pendidikan vokasi merupakan jawaban atas tantangan pemenuhan kebutuhan kerja, dinegara barat perkembangan 
pesat pendidikan vokasi dimulai pada era revolusi industri, sekitar tahun 1800-an. Dengan semakin berkembangnya pendidikan vokasi pada masa ini terutama di Indonesia, sangat dibutuhkan penanganan khusus, sehingga perkembanganya sesuai dengan kebutuhan, maka dibutuhkan pemimpin yang mampu mengembangkan dan mengolah pendidikan kejuruan tersebut. Dalam Permendiknas No.28 tahun 2010, menyebutkan secara jelas tentang kepemimpinan pendidikan, dalam hal ini adalah kepala sekolah, kompetensi tersebut adalah kompetensi kepribadian, kompetensi manajerial, kompetensi supervisi, kompetensi sosial. Perkembangan pendidikan kejuruan yang pesat sangat membutuhkan pemimpin yang visioner, artinya dibutuhkan pemimpin yang benar-benar memahami konsep yang perlu dijalankan dan dikembangkan dalam pendidikan kejuruan. Pemimpin yang mampu untuk menjalankan roda organisasi dalam pendidikan kejuruan seharusnya adalah orang yang berkecimpung langsung dengan pendidikan kejuruan tersebut.

School leaders [...] have agreed from the start that effective school leadership is not exclusive to formal offices or positions; instead it should be distributed across a number of individuals in a school. Principals, managers, academic leaders, department chairs, and teachers can contribute as leaders to the goal of learning-centred schooling. [...] Thus principals must be not only managers but also leaders of the school as a learning organisation. They interact with teachers to create a productive, cohesive learning community (OECD, Pont et al., 2008:16), Pimpinan Sekolah [...] telah di sepakati di awal, bahwa kepemimpinan disekolah yang efektif tidak seeksklusif seperti pada posisi dikantor , melainkan harus didistribusikan dari sejumlah individu di sekolah tersebut. Prinsip, manajer, pemimpin akademis, kepala departemen , dan guru dapat berkontribusi sebagai pemimpin yang bertujuan sebagai pusat pembelajaran dalam pendidikan . [...] Jadi kepala sekolah adalah tidak hanya sebagai manajer, tetapi juga pemimpin organisasi dan pembelajaran di sekolah. Pemimpin berinteraksi dengan guru untuk menciptakan kondisi produktif dan komunitas pembelajaran kohesif). Sedangkan menurut Evan dan Herr. (1978:292) potential leaders need to be identified as well as to be trained. too often the identification process has been left to chance.at the local level, vocational education leadership potential is rarely surveyed until an administrative opening has occured through death, resignation, or expansion of the program, (pemimpin yang potensial seharusnya diidentifikasi dan didilatih terlebih dahulu, identifikasi kepemimpinan pendidikan kejuruan seharusnya mempertimbangkan tingkatan administrasi secara detail, namun pada kenyataanya, potensi kepemimpinan dilihat 
setelah pemimpin yang menjalankan tugas mengundurkan diri, meninggal atau pada saat pengembangan program).

\section{Konsep LMX dalam Pendidikan Kejuruan}

Berjalanya sebuah organisasi tidak lepas dari peran penting seorang pemimpin, pemimpin merupakan seorang yang tidak hanya sekedar mempengaruhi bawahan agar bisa menjalankan perintah, namun harus juga dapt membaur dengan lingkungan dan organisasinya untuk bersamasama meraih tujuan organisasi. Laurie (2005:282) kepemimpinan adalah “... a relationship through which one person influences the behaviour or actions of other people."( hubungan yang dilalui seseorang dimana dapat mempengaruhi perilaku atau tindakan orang lain), sedangkan menurut Northouse (2010:3) yaitu “... is a process whereby an individual influences a group of individuals to achieve a common goal." (... adalah proses dimana seorang individu mempengaruhi sekelompok individu guna mencapai tujuan bersama).

Seperti yang telah disebutkan sebelumnya bahwa pendidikan vokasi mempunyai fondasi untuk menciptakan peserta didik yang pada akhirnya memiliki kesiapan kerja pada bidang keahlian masing-masing. Seiring perkembangan jaman, tantangan pendidikan vokasi akan semakin berat dalam mewujudkan tujuan itu, sehingga sangat dibutuhkan pemimpin yang mengetahui secara keseluruhan tentang pendidikan vokasi.

Kecenderungan kepemimpinan pendidikan vokasi di Indonesia masih dicampur adukkan dengan kepentingan-kepentingan diluar pendidikan, maka yang terjadi adalah tersendatnya tujuan pendidikan tersebut karena pemimpin yang dipilih bukan pemimpin yang kompeten pada bidangnya. Dengan melihat kondisi tersebut maka sebaiknya masalah itu dapat disikapi dengan baik, kebijakan-kebijakan dalam menempatkan pemimpin dalam dunia pendidikan terutama pendidikan vokasi. Hal utama yang dibutuhkan dalam pendidikan adalah pola kepemimpinan pendidikan yang sangat efektif, Bishop (2008:13) kepemimpinan pendidikan yang effektif adalah Kepemimpinan yang efektif, 1). Menetapkan dan mengembangkan target tertentu agar kemajuan dapat ditampilkan, dimonitor dari waktu ke waktu dan ditindaklanjuti, 2). Mendukung pengembangan dan pelaksanaan hubungan pedagogik baru dan interaksi di dalam kelas, 3).Melakukan perubahan institusi, organisasi dan struktur, 4). Mereformasi yang mencakup staf, orang tua, masyarakat, pengembang dan pembuat kebijakan reformasi sehingga budaya sekolah yang baru dapat di tanamkan dan dikembangkan, 5). Mengembangkan kapasitas masyarakat dan 
sistem untuk memproduksi dan menggunakan bukti kemajuan siswa untuk menginformasikan perubahan, 6). Mempromosikan dan memastikan bahwa reformasi telah berjalan dalam sekolah. Pola kepemimpinan LMX dianggap cocok untuk dapat diterapkan dalam pendidikan vokasi. Ngoma (2011:12), Effective leadership relationships would develop among dyad "partners" encompassing school principals, teachers, counselors, department chairs, and other administrators. Sehingga dengan mengadopsi pola kepemimpinan LMX maka diharapkan kepemimpinan pendidikan vokasi, terjadi pola kepemimpinan yang berbeda dengan kondisi saat ini, dengan metode pertukaran pimpinan- bawahan akan membentuk pemimpin yang mempunyai hubungan khusus dengan semua bawahan, dalam hubungan ini pemimpin harus menawarkan kesempatan pada bawahan untuk mempunyai peran / tanggung jawab baru dalam organisasi dan proses kerja, dengan demikian dalam pola kepemimpinan vokasi, tidak lagi memikirkan masalah perbedaan, pemimpin harus fokus pada cara membangun kepercayaan \& saling menghormati dengan semua bawahan, sehingga seluruh kelompok kerja menjadi satu kesatuan dalam mencapai tujuan organisasi.

Trust, respect dan obligation dalam LMX dalam pendidikan vokasi akan meningkatkan motivasi, kinerja serta komitmen terhadap organisasi, yang tujuan utamanya adalah menciptakan kemajuan dalam pendidikan vokasi , peningkatan mutu pendidikan dan mengimplementasikan tujuan standar kelulusan pada pendidikan vokasi di Indonesia dalam sikap, keterampilan dan pengetahuan. High LMX relationship is characterized by respect, trust, and mutual obligation (Graen \& Uhl-Bien,1995). Menurut George dan Jones (2005:175), "motivasi kerja dapat didefinisikan sebagai suatu dorongan secara psikologis kepada seseorang yang menentukan arah dari perilaku (direction of behavior) seseorang dalam organisasi, tingkat usaha (level of effort), dan tingkat kegigihan atau ketahanan di dalam menghadapi suatu halangan atau masalah (level of persistence)". Maka dapat digaris bawahi bahwa motivasi merupakan semangat pada masingmasing individu dalam mencapai sebuah tujuan yang akan dituju, berkaitan dengan komitmen Porter et al. dalam Tobing (2009:32) mendefinisikan komitmen organisasional sebagai kekuatan relatif individu terhadap suatu organisasi dan keterlibatannya dalam organisasi tertentu, yang dicirikan oleh tiga faktor psikologis: (1) Keinginan yang kuat untuk tetap menjadi anggota organisasi tertentu, (2) Keinginan untuk berusaha sekuat tenaga demi organisasi dan (3) Kepercayaan yang pasti dan penerimaan terhadap nilai-nilai dan tujuan organisasi. Penerapan LMX dalam pendidikan kejuruan dapat jelaskan pada gambar.3 

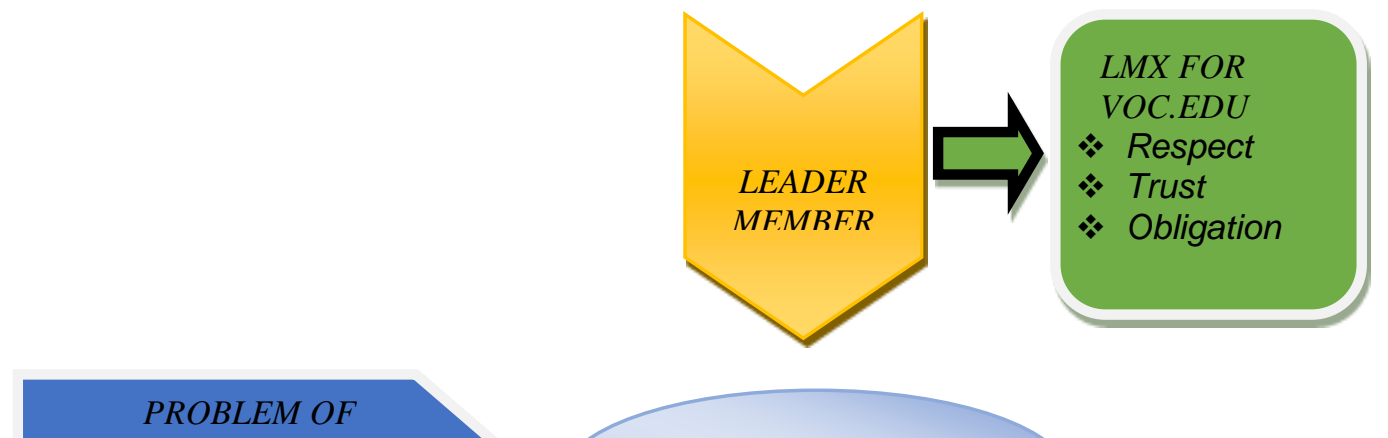
VOCATIONAL EDU.LEADERSHIP

Kompetensi Pemimpin tidak relevan dengan kebutuhan pendidikan vokasi.

$>$ Perkembangan pendidikan kejuruan macet.

$>$ Unsur politik muncul dalam penetapan pendidikan vokasi.

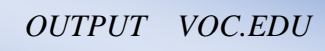

$>$ Competence Skill Of Voc. Edu Leadership

> Perkembangan pendidikan vokasi

$>$ Pemimpin dipilih bukan karena politik

$>$ Keahlian memimpin menyeluruh bagi organisasi

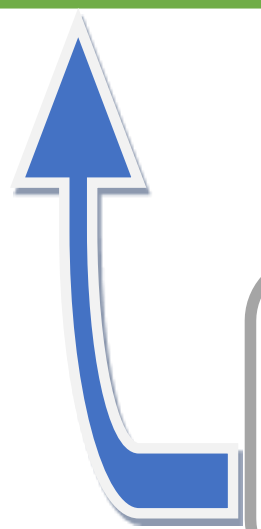

...

- Respect terhadap keahlian dan kemampuan orang lain

- Trust each other, tanpa saling percaya organisasi tidak berjalan

- Obligation, menjalankan kewajiban dengan penuh

Gambar.3 Leader Member Exchange Teori dalam Pendidikan Vokasi 


\section{Kesimpulan}

Meningkatkan mutu pendidikan kejuruan, tidak lepas dari peran pemimpin dalam menjalankan organisasi sekolah, perlunya diganti sistem kepemimpinan pendidikan kejuruan yang berlaku saat ini, pemilihan pemimpin masih berdasarkan pada kepentingan golongan atau politik, tidak mempertimbangkan keahlian kompetensi dan keahlian yang dimiliki individu, pola pemilihan seperti ini, tidak memberikan kontribusi yang baik bagi perkembangan dan kemajuan pendidikan kejuruan, yang terjadi selanjutnya adalah pembunuhan karakter individu yang berada dalam sistem pendidikan kejuruan, tidak berkembangnya keahlian masing-masing individu, jenjang karier yang macet, dan lain sebagainya. Leader Member Exchange, memberikan konsep yang dapat menjawab dan menggantikan sistem yang berlaku saat ini, dengan Leader Member Exchange akan terbangun sinergi antara atasan dan bawahan dalam mengembangan organisasi pendidikan kejuruan, dengan mengusung konsep trust, rescpect dan obligation.

\section{Daftar Pustaka}

Bass, B. M. (1985). Leadership and performance beyond expectations. New York: Free press.

Bass, B.M (2000) . The Future of Leadership in Learning Organizations. Journal of Leadership \&amp; Organizational Studies 2000; 7; 18. doi:10.1177/107179190000700302.Online diakses dari http://jlo.sagepub.com/cgi/content/abstract/7/3/18.

Bishop.R (2008). Effective Leadership for Educational Reform. Report to Nga Pae o Marmatamanga. Waikato University, diakses dari http://www.maramatanga.ac.nz

Calhoun.C. C dan Finch. A. V. 1982.Vocational Education Concept and Operation. Belmont, California. Wadsworth Publishing Company.

Evans.R.N dan Herr.E.L.(1978). Foundation of Vocational Education, 2nd edition. Columbus, Ohio. Charles E. Merril Publishing Company A Bell \& Howell Company.

George, J.M., Jones, G.R. (2005). Understanding and Managing Organizational Behavior (4th ed.). New Jersey: Upper Saddle River.

Graen, G. B.; Uhl-Bien, M. (1995). "The Relationship-based approach to leadership: Development of LMX theory of leadership over 25 years: Applying a multi-level, multidomain perspective".Leadership Quarterly 6(2): 219-247. doi: $10.1016 / 1048$ 9843(95)90036-5.

Laurie, J.M.(2005). Management and Organisational Behavior, $7^{\text {th }}$ Edition, Essex: Pearson Education Limited.

Muhransyah.M (2013). Lelang Jabatan Kepala Sekolah, Kenapa tidak?, Surat kabar Radar Banjarmasin Jawa Pos Group, on line diakses dari 
http://www.radarbanjarmasin.co.id/berita/detail/57296/lelang-jabatan-kepala-sekolahkenapa-tidak.html.

Ngoma.S (2011). The Impact of Leader-Member Exchange Theory on Education: Leveraging the Power of 'In-Group' and 'Out-Group' to Enhance School Effectiveness. On line, diakses dari http://www.congovision.com/science/NG-LMX-Paper.pdf

Northouse.P.G (2010) Leadership : Theory and Practice, Fifth Edition. Thousand Oaks, California : SAGE Publication.

OECD (2008). Improving School Leadership. Executive summaries. Online Diakses dari http://www.oecd.org/dataoecd/6/52/40545479.pdf pada tanggal 25 oktober 2013.

Permendiknas No.28 Tahun 2010. Tentang Penugasan Guru Sebagai Kepala Sekolah/Madrasah.online.diakses dari http://staff.unila.ac.id/radengunawan/files/2011 pada tanggal 22 Oktober 2013.

Robbins, S., and Judge, T. (2007). Organizational Behavior (12th ed.). New Jersey: Prentice Hall.

Tobing, D.S.K.L. (2009). Pengaruh Komitmen Organisasional dan Kepuasan Kerja Terhadap Kinerja Karyawan PT. Perkebunan Nusantara III di Sumatera Utara. Jurnal Manajemen Dan Kewirausahaan Vol.11, No. 1. Maret 2009: 31-37 